\title{
Stupika Dan Votive Tablet Borobudur
}

\author{
Oleh \\ Agustijanto Indradjaya \\ Pusat Penelitian dan Pengembangan Arkeologi Nasional
}

\section{Pengantar}

Borobudur sebagai candi Buddha terbesar yang didirikan sekitar abad ke -9 M merupakan salah satu pencapaian masterpiece dalam seni arsitektur bangsa Indonesia yang cukup membanggakan. Oleh karena itu tidaklah salah jika pemerintah dengan bantuan Unesco melakukan pemugaran total di candi ini untuk menghadirkan kembali 'kejayaan' tersebut sebagai warisan bangsa. Dalam upaya pemugaran tersebut juga dilakukan penggalian di sejumlah lokasi yang diduga memiliki kaitannya dengan keberadaan candi Borobudur. Salah satunya di sisi barat daya candi Borobudur yang menemukan 252 votive tablet dan 2307 stupika tablet yang tidak dibakar di dalam sebuah lubang. Di bawah konsentrasi temuan votive dan stupika tablet ditemukan lima wadah tembikar yang disusun ke arah empat mata angin dan satu di tengah. Di samping itu ditemukan pula dua fragmen arca yang tidak dapat diidentifikasi. Tampaknya votive dan stupika tablet ini diletakkan di bawah arca tersebut ( Boechari,1976; Boechari dkk,1982: 115).

Votive tablet adalah simbol/ icon Buddha berukuran kecil yang terbuat dari tanah liat yang dicetak dengan teknik tekan untuk selanjutnya dibakar atau bisa pula hanya dijemur. Votive yang telah dicetak ini dibakar selama beberapa jam dalam lubang yang dangkal dan ditutup oleh bahan yang mudah terbakar seperti kayu atau daun-daun kering. Sedangkan votive yang tidak dibakar hanya diletakkan di tempat yang terbuka sampai kering akibat panas matahari dan tentunya votive yang tidak dibakar jauh lebih mudah rusak dibandingkan dengan yang dibakar. Votive tablet yang tidak dibakar ini mungkin karena bahan yang digunakan untuk pembuatan votive dicampur dengan abu jenazah dari guru atau leluhurnya. Abu jenazah ini digunakan untuk memindahkan kekuatan api (Stanley, 1974:83). Namun di Indonesia tidak ditemukan indikasi adanya abu jenasah yang dicampurkan untuk bahan pembuatannya. Berdasarkan hasil analisis laboratorium terhadap stupika tablet dari situs Gumuk Klinting, Muncar (Banyuwangi) dan situs Sarangwati (Palembang) diketahui bahwa stupika tablet Banyuwangi dibuat dari campuran tanah liat dan feldspar sedangkan stupika tablet dari Palembang dibuat dari campuran tanah liat dan tuff) (Hardiati, 1983:87). Stupika tablet adalah miniatur stupa dalam bentuk yang mini yang terbuat dari tanah liat dan selanjutnya dikeringkan dengan dijemur di terik matahari. Sebagai miniatur dari stupa maka bagian-bagian dalam stupika tablet mengacu kepada bentuk stupa. Bagian-bagian dari stupa ini memiliki makna simbolis dari benda-benda yang dimiliki sang Buddha di dunia. Bagian dasar (prasada) yang berbentuk persegi empat merupakan perlambangan dari bentuk jubah sang Buddha yang dilipat, badan stupa (anda) yang bentuknya setengah bola adalah bentuk mangkok yang selalu dibawa oleh sang Buddha, sedangkan yasti adalah representasi tongkat yang selalu dibawa oleh sang Buddha.

Berdasarkan peruntukannya stupa dibedakan menjadi: (1) stupa jenis uddesika yakni stupa stupa sebagai

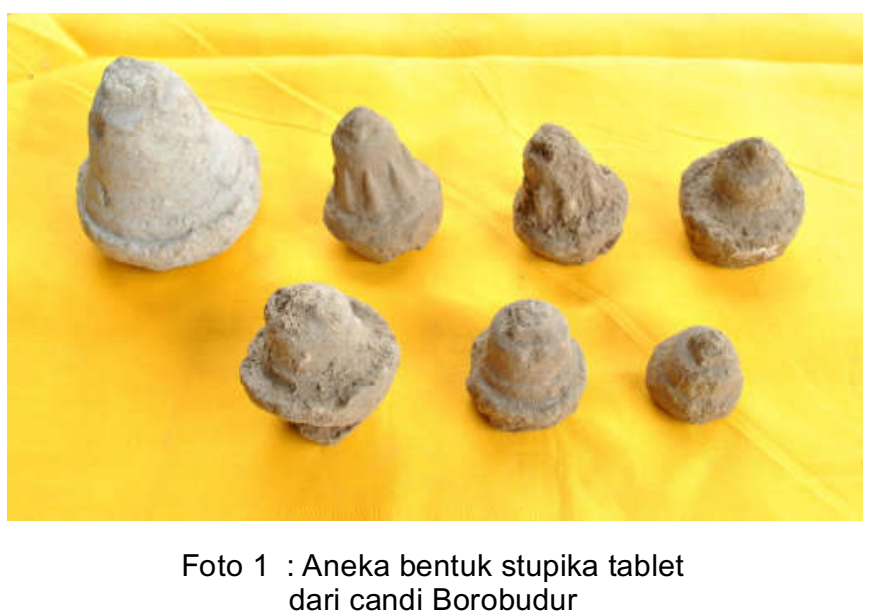

tanda peringatan pada tempat - tempat dan peristiwa penting dalam kehidupan Buddha. (2) Stupa jenis kedua adalah stupa sebagai benda persembahan dibuat dengan suatu keyakinan akan memperoleh pahala (dànapati) karena telah melaksanakan korban (yajamana), mematuhi perintah/ ajaran tentang kebebasan (dāna) dan mencapai kesempurnaan dana (dāna päramita)(Snodgrras,1985:357; Basuki,1992:72). Stupa jenis kedua ini bisa memiliki berbagai ukuran dan untuk stupa berukuran kecil (stupa yang memiliki tinggi sekitar 4-20 cm ) biasa disebut dengan stupika tablet. Stupika tablet (miniatur stupa) ini 
dapat dibuat dengan cetakan namun dapat pula dibentuk hanya dengan kedua tangan saja (hand made) sehingga menghasilkan bentuk yang sangat variatif.

Dari informasi ini diketahui bahwa votive tablet selalu dibawa oleh para peziarah bersama-sama dengan stupika tablet (miniatur stupa). Namun pada kenyataan, pada situs-situs bersifat buddhistik tidak selalu keduanya ditemukan. Selain itu stupika tablet yang ditemukan seringkali digunakan untuk meletakkan materai tablet (seal tablet) yang berisi mantra-mantra Buddha. Votive tablet ini mempunyai beberapa bentuk seperti bulat (seperti mata uang), bujur sangkar, atau empat persegi panjang dengan hiasan (relief) pada salah satu sisinya. Sedangkan motif hias biasanya menggambarkan Dhyāni Buddha, dan Dhyāni Boddhisattva. Seluruh relief dibuat dengan teknik cetak ketika bahan tanah liat masih dalam keadaan basah. Demikian pula halnya dengan stupika dan materai tablet.

Temuan ini cukup menarik mengingat kedua artefak tersebut merupakan bagian yang cukup penting dalam kegiatan keagamaan pada masa itu. Beberapa kajian telah dilakukan terhadap temuan votive tablet yang memang memiliki bentuk cukup bervariasi. Sayangnya kajian terhadap votive tablet tidak dilakukan secara mendalam. Oleh karena itu tulisan ini akan mengulas kembali temuan votive tablet Borobudur dan mencoba melakukan perbandingan dengan temuan serupa di Nusantara. Metode yang digunakan adalah teknik penelitian deskriptif dengan tipe penalaran induktif. Melalui teknik ini seluruh votive tablet yang mewakili temuan dari candi Borobudur akan di deskripsi, dianalisis dan ditarik kesimpulan secara general.

\section{Votive Tablet Borobudur}

Votive tablet yang ditemukan menggambarkan Buddha duduk dalam berbagai asana demikian pula dengan posisi tangan yang ditemukan dalam berbagai mudra. Adapun berdasarkan tokoh yang digambarkan di dalam Votive tablet maka Votive tablet Bororbudur dapat dibedakan menjadi 5 jenis yakni:

Votive tablet tipe 1 berbentuk bulat namun bagian belakang rata, tokoh dicetak begitu dalam seolah-olah berada di dalam relung. Kondisi votive tablet sudah rusak namun masih dapat dikenali tokoh yang digambarkan meskipun tidak begitu detail. Votive tablet menggambarkan Dhayni Boddhisattva

Avalokiteśvara dalam posisi duduk maharajalilasana bertangan empat. Tangan kanan atas diletakkan menopang kepala. Kemudian tangan kanan bawah diletakkan di atas paha kanan dalam posisi waramudra. Tangan kiri atas diletakan di samping kepala

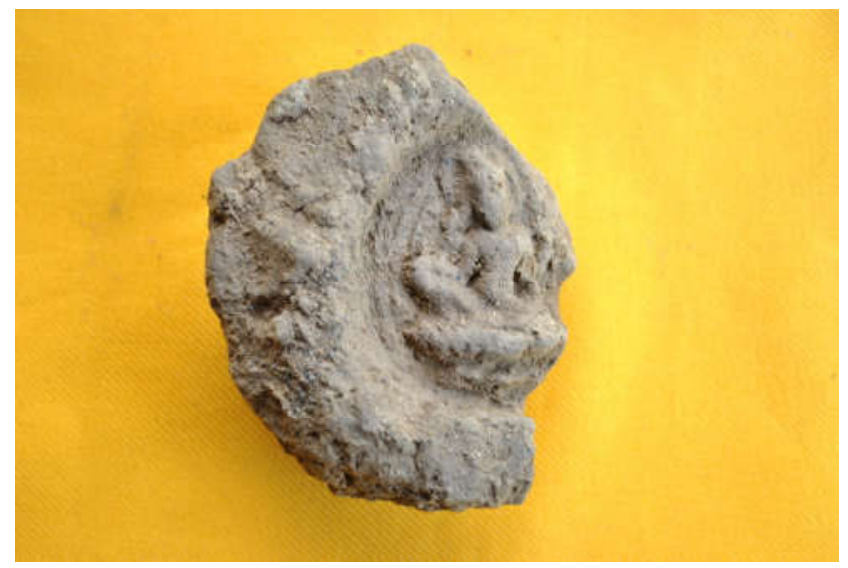

Foto 2 : Votive tablet yang menggambarkan Dhyani Buddhisattva Avalokiteśvara

dengan membawa laksana dan tangah kiri bawah kemungkinan diletakkan di atas tempat duduk seolah menyangga (Nandana,1994:100). Tokoh digambarkan memakai kirita mahkota dan silascakra sebagai lambang kedewaan dan duduk di atas padmaganda.

Votive tablet tipe 2 berbentuk bulat namun bagian belakang rata, tokoh dicetak begitu dalam seolaholah berada di dalam relung. Kondisi votive tablet sudah rusak namun masih dapat dikenali tokoh yang digambarkannya. Tokoh yang digambarkan adalah Buddha Aksobhya dengan sikap tangan bersikap Bhumisparsa mudra dan tangan kiri diletakkan di depan perut dalam posisi duduk bersila (varamudra) di atas

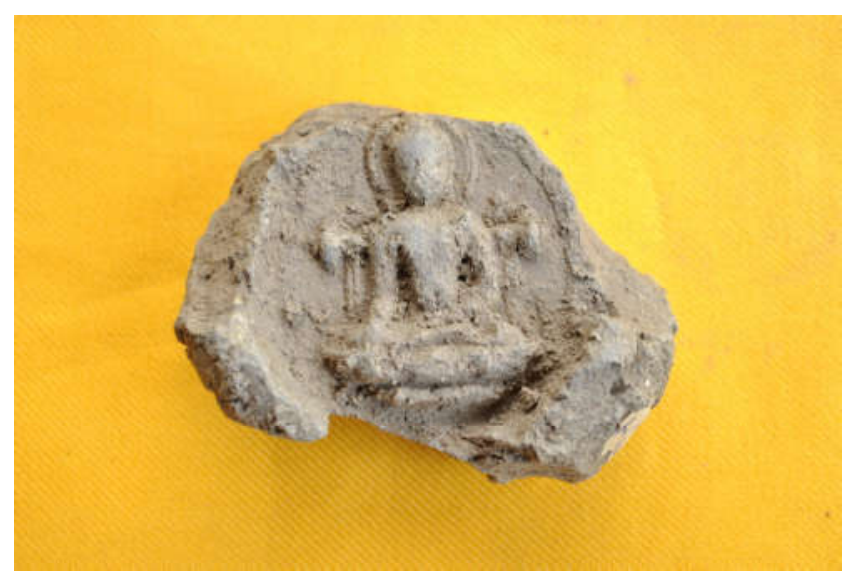

Foto 3 : Votive tablet yang menggambarkan Dhyani Buddha Aksobhya

padmasana. Tokoh juga mengenakan rambut yang diikat ke atas dan memakai silascakra. Selain itu juga tokoh digambarkan duduk dengan sandaran arca.

Votive tablet tipe 3 berbentuk bulat namun bagian belakang rata, tokoh dicetak begitu dalam seolaholah berada di dalam relung. Kondisi votive tablet sudah rusak namun masih dapat dikenali tokoh yang digambarkannya. Tokoh adalah seorang dewi Tara yang digambarkan dalam posisi duduk bersila dan tangan kanan di atas lutut kanan sedangkan tangan kiri diletakkan 
di depan dada kiri.

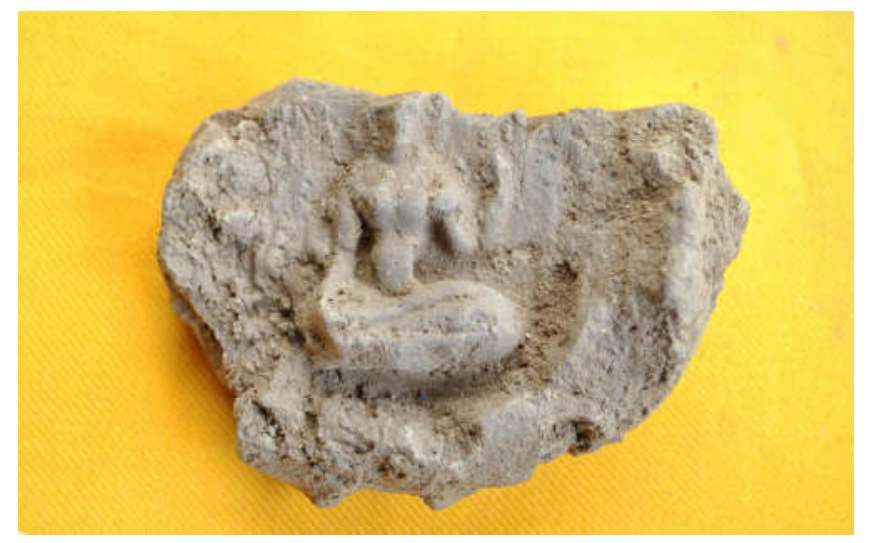

Foto 4 : Votive tablet yang menggambarkan Dewi Tara

Votive tablet tipe 4 tergolong kepada votive tablet berukuran besar karena diameter votive $13 \mathrm{~cm}$ dan merupakan votive tablet terbesar yang pernah ditemukan. Bentuknya bulat dengan bagian belakang rata. Votive dicetak cukup dalam seolah-olah berada di dalam relung. Kondisi sudah fragmentaris namun masih cukup dapat dikenali. Relief menggambarkan seorang tokoh yang dilukiskan di dalam sebuah relung dengan hiasan berupa sebuah payung pada bagian atas relung dan padmasana di bagian bawah relung. Tokoh yang digambarkan adalah Buddha Vairocana dengan posisi tangan Dharmacakramudra dalam posisi duduk bersila Di sekeliling relung tersebut digambarkan sejumlah stupa mengelilingi relung yang disusun dalam empat baris. Dari yang tersisa tampak ada sekitar 12 stupa dan bagian stupa yang digambarkan adalah anda, harmika dan yasti.

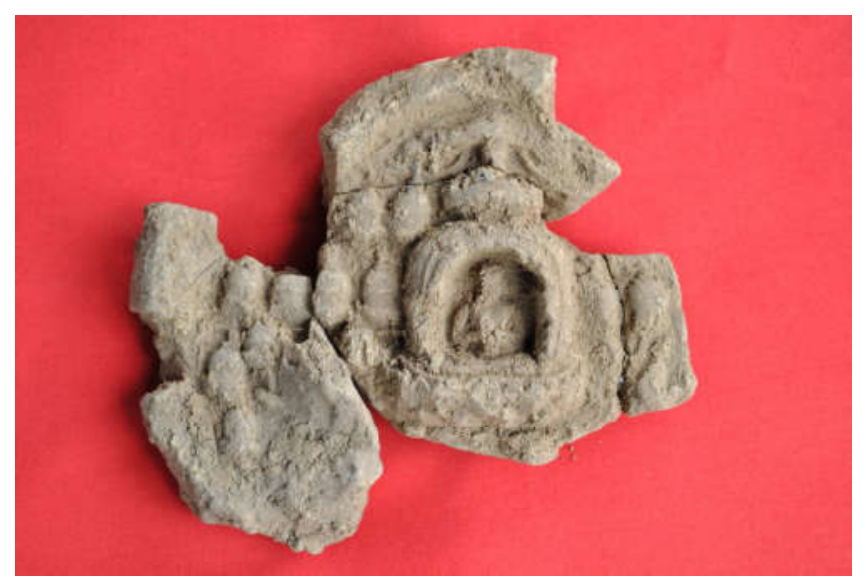

Foto 5 : Votive tablet yang menggambarkan Buddha Vairocana

Votive tablet tipe 5 berbentuk bulat namun bagian belakang rata, Relief pada bagian dalam dibuat dengan dicetak begitu dalam seolah-olah berada di dalam relung. Relief yang digambarkan adalah tiga buah stupa disusun berjajar dengan stupa bagian tengah berukuran paling besar.

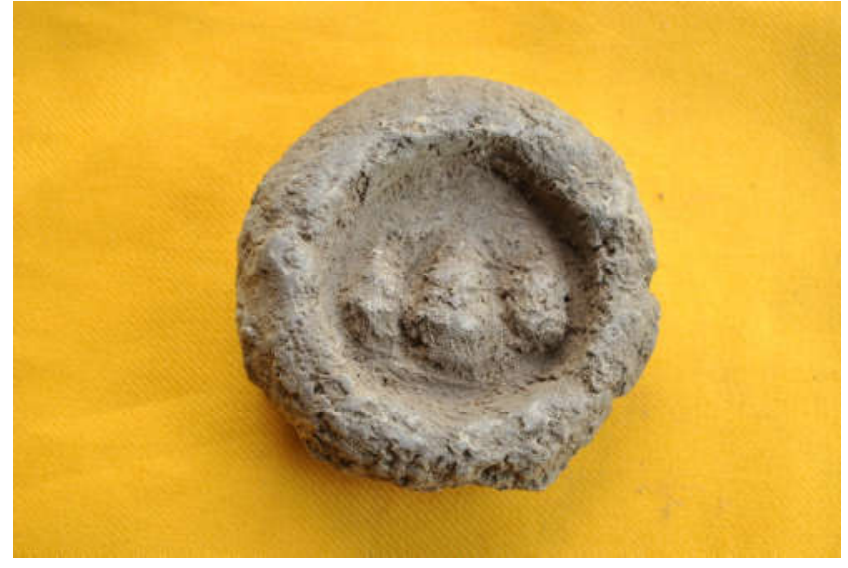

Foto 6 : Votive tablet yang menggambarkan tiga buah stupa

Terkait dengan pertanggalan dari votive, materai dan stupika tablet di candi Borobudur maka tentunya keberadaan terkait dengan aktivitas keagamaan yang dilaksanakan di candi Borobudur. Menurut J.G.de Casparis, Candi Borobudur didirikan sekitar tahun $824 \mathrm{M}$, Hal ini didasarkan atas sebuah prasasti yang dikenal sebagai prasasti Kayumwungan (Karang Tengah) tentang peringatan pembangunan candi Borobudur oleh Samarātungga dan Prāmodāwarddhanī (Bambang, 1990 $: 113)$.

\section{Diskusi}

Dari paparan data di atas ada beberapa hal yang menarik. Pertama, Pemakaian stupika tablet di Nusantara telah digunakan setidaknya sejak abad ke-8 M seperti yang ditemukan di pusat-pusat studi Buddha di Palembang, Jawa Tengah dan Bali. Stupika tablet ini ada yang dibuat dengan cetakan tapi ada pula yang dibuat dengan tangan (hand made). Biasanya bahan tanah liat diambil dari sekitar lokasi keagamaan sedangkan cetakan stupika merupakan barang kecil yang mudah dibawa seperti temuan cetakan stupika dari perunggu yang ditemukan di Palembang. Cetakan ini bisa saja dibuat di daerah sekitar lokasi keagamaan atau mungkin dibuat di suatu tempat lalu dibawa oleh para penganut Buddha ke tempat-tempat suci agama Buddha. Cetakan stupika seperti ini juga ditemukan di kargo kapal Intan yang tenggelam di laut Jawa. Cetakan stupika Palembang dan kapal Intan ini memiliki bagian dasar berupa padma, dengan delapan stupa kecil yang mengelilingi stupa di bagian tengah dan tidak memiliki hiasan ini mirip dengan stupika tablet yang ditemukan di Bodhgaya, India (Guy,2002:26) .

Namun sebenarnya pembuatan stupika telah lama dilakukan di India. I-tsing dalam catatan perjalanannya di India telah melaporan adanya kegiatan membuat stupika. Dalam catatannya ia menulis 
“... (Buddhists in India) make ..paste caityas.(i.e.,miniatur stupa/stupikas) and paste images from rubbings... (which they) impress.. on silk or paper..Among the monks and laity of India, they all take this as their practice. Furthermore, whether they build images or make caityas, be they of gold, silver, bronze, iron, paste, lacquer, brick, or stone... they place inside (them) two kinds of relics. One is called the bodily relic of the great teacher, the second is called the dharma-verse relic on causation. This verse goes as follow:

All thing arise from a cause

The Tathagata has explained their cause

And the cessation of the cause of these things

This the great ascetic has explained

If one install these two (relic), then one's blessings will be extremely abundant (ibid:25)

Adapun motivasi para penganut Buddha di India membuat stupika seperti yang dilaporkan oleh Hsuen Tsang, seorang Buddhist dari Cina yang melakukan perjalanan ke Cina pada abad ke-7 $\mathrm{M}$ adalah untuk mendapatkan kebaikan yang paling tinggi dalam agama Buddha. Menurut Hsuen Tsang "..It is the custom in India (for devout Buddhist) to make little stupa..(W)ith his hand be construted these stupa. Thus he acquired the highest and most excellent religious merit. Hal ini tampaknya sesuai dengan yang dijelaskan dalam sutra on the merit of bathing the Buddha yang menyatakan "..if someone writes the dharma verse and install it inside the stupa, it would be like doing homage by offering up a rare jewel "(ibid,24-25).

Dalam prakteknya, stupika tablet yang ditemukan dapat dikelompokkan menjadi tiga pula yakni besar, sedang dan kecil. Ukuran paling besar stupika tablet yang pernah ditemukan sekitar tinggi $20 \mathrm{~cm}$ dan ukuran terkecil sekitar $4 \mathrm{~cm}$. Perbedaan ukuran ini juga menunjukkan perbedaan pada perlakuan, dimana stupika paling besar biasanya diletakkan di dalam lubang paling bawah baru secara berurutan dari yang berukuran besar, ukuran sedang sampai yang teratas adalah stupika berukuran kecil. Seperti yang telah disebutkan bahwa stupika tablet ini seringkali digunakan untuk menyimpan materai tablet di bagian dalam. Materai tablet dimasukkan/ disisipkan ke dalam stupika tablet ketika bahan tanah liat (bakal stupika) akan dibentuk menjadi stupika tablet. Dalam satu stupika tablet seringkali ditemukan lebih dari satu materai tablet.

Selain dimasukan ke dalam stupika tablet, bagian dasar (prasada) stupika tablet kadang kala langsung diberi mantra-mantra Buddha yang dibuat dengan cara mentera (cap) mantra tersebut ketika stupika tablet masih dalam kondisi basah. Seringkali mantra mantra yang diterakan pada bagian dasar (prasada) stupika lebih dari satu kali. Mantra-mantra yang diterakan pada stupika ini ditemukan pada beberapa stupika tablet dari candi Borobudur.
Seperti halnya stupika tablet, votive tablet yang ditemukan di Candi Borobudur erat kaitannya dengan menguatnya pengaruh Buddha Mahāyāna di Nusantara sekitar abad ke-8 M. Adanya dua pusat studi di Sriwijaya dan Jawa memberi dampak bagi berkembangnya Buddha Mahāyāna sampai ke Kalimantan, Bali dan Nusa Tenggara Barat. Menguatnya Mahāyāna di Jawa Tengah didukung oleh kalangan Istana dimana salah satu penguasa di Jawa Tengah dari wangsa Sailendra banyak membangun bangunan seperti pembangunan candi Borobudur pada sekitar tahun $824 \mathrm{M}$, candi Kalasan pada tahun 700 çaka (778 M) yang diperuntukan bagi Dewi Tara, dan pemujaan kepada Dhyani Bodhisattva Avalokiteśvara maupun peresmian patung Bodhisattva Majusri.

Selain menggambarkan tokoh Dhyāni Buddha dan Dhyāni Bodhisattva, ditemukan pula votive tablet yang menggambarkan stupa. Penggambaran stupa pada votive tablet ditemukan cukup bervariasi. Penggambaran stupa dari votive tablet situs Gumuk Klinting pada bagian yasthi memakai bendera pada bagian puncaknya sedangkan penggambaran stupa pada votive tablet dari situs Uma Anyar menggambarkan cattra yang bertingkat delapan sedangkan stupa yang digambarkan pada Votive tablet Borobudur disusun berjajar sebanyak tiga buah.

Dilihat dari konteks temuan dari sejumlah stupika dan votive tablet di candi Borobudur maka stupika dan votive tablet yang ditemukan di bawah arca seperti yang ditemukan Candi Borobudur tampaknya memiliki kesamaan tujuan dengan temuan stupika, materai, dan votive tablet di ditemukan di bagian tengah pondasi (sumuran) sebuah bangunan pemujaan seperti yang terjadi di situs Kalibukbuk (Bali) dan di Pura Pagulingan (Bali) (Sutaba,1992:15). Hal ini menimbulkan dugaan bahwa penempatan materai di dalam bangunan suci/ arca tokoh ini dimaksudkan untuk menciptakan suasana sakral di sekitar komplek pemujaan. Seperti diketahui bahwa bangunan suci merupakan tempat yang paling sakral dan merupakan rumah bagi para dewa. Demikian pula dengan arca tokoh dalam agama Buddha yang tentunya sangat dihormati dan disakralkan. Oleh karena itu perlu diciptakan suasana yang sakral di sana. Untuk menghadirkan suasana itulah ketika pembangunannya/ peletakan arca tokoh diletakkan/ ditanamkan votive, stupika dan materai yang berisi mantra-mantra Buddha sebagai peripih (ritual deposit).

Namun tidak menutup kemungkinan bahwa votive dan stupika tablet tersebut juga memiliki fungsi diluar dari yang telah disebutkan di atas. Dari beberapa sumber diketahui bahwa votive tablet dapat pula digunakan yantra yakni sebagai alat meditasi, atau pada votive tablet yang bergambar Dewa Jambhala, votive ini 
kemungkinan juga digunakan sebagai jimat bagi para pedagang agar memperoleh hasil yang besar dalam usahanya. Hal ini jika dihubungkan dengan kapasitas dewa Jambhala sebagai dewa kemakmuran. Di Thailand, votive tablet digunakan juga sebagai penghias bangunan suci dengan cara menempelkan votive tablet tersebut pada bagian tertentu dari bangunan candi/ stupa. Sedangkan di Tibet, votive tablet digunakan di altar altar candi atau altar keluarga di rumah. Votive tablet tersebut kadang kadang dibuat oleh Lama dan dijual kepada para peziarah. Selain menggambarkan dewa dewa dalam pantheon Buddha, juga digambarkan tokoh dewa lokal seperti dewa perang beg tse. Pada bagian belakang votive tablet terdapat tulisan yang berisi mantra-mantra Buddha (Gordon, 1963:76; Basuki,1992:73).Di Bali, pada sekitar tahun 1930-an, Stutterheim menyampaikan bahwa stupika tablet merupakan tanda ziarah/ suvenir bagi seseorang yang mengunjungi tempat-tempat suci dan mempergunakannya sebagai nazar. Di Blahbatu, Bali, stupika tablet ditanam di perempatan jalan desa yang fungsinya adalah untuk menolak bala dan adapula yang mempergunakannya untuk membuat air suci dengan mencelupkannya ke dalam kolam dengan harapan dapat memberikan kesembuhan dari penyakitnya Issatriadi,1976:10).

\section{PENUTUP}

Dari uraian diatas dapat diambil beberapa kesimpulan di antaranya adalah stupika dan votive tablet telah digunakan dalam aktivitas agama Buddha di Nusantara sejak Sriwijaya dan Jawa menjadi pusat pendidikan Buddha di Asia Tenggara. Pengaruh ini datang dan disebarkan dari India ke Asia Tenggara bersamaan dengan meningkatnya hubungan perdagangan antara India dan Asia Tenggara termasuk Indonesia. Tujuan dari pembuatan stupika, materai dan votive tablet ini adalah untuk mendapatkan kebaikan, karena dipercaya bahwa sesiapa yang membuat mantra Buddha dan memasukkan ke dalam stupa seolah-olah ia telah memberikan penghormatan kepada Sang Buddha dengan mempersembahkan batu berlian yang sangat langka. Di samping itu mempersembahkan stupika atau votive tablet dipercaya juga sebagai salah satu jalan berbuat kebaikan untuk mendapatkan kebaikan dan keselamatan dari sang Buddha. Oleh karena itu kedudukan stupika dan votive tablet menjadi hal yang penting dalam setiap upacara keagamaan pada masa itu.

Stupika tablet yang ditemukan di Nusantara pada awalnya memiliki bentuk yang mirip dengan yang biasa digunakan India sehingga ada anggapan bahwa cetakan stupika yang ditemukan di Palembang dan pada kapal tenggelam di Laut Jawa berasal dari India. Hal ini tidaklah mengherankan karena bentuk cetakan stupika ini cukup kecil dan mudah untuk dibawa-bawa. Namun dalam perkembangannya stupika tablet kemudian memiliki variasi bentuk yang sangat banyak seperti yang ditemukan di Palembang, Borobudur, Banyuwangi, dan Bali. Jelas bahwa bentuk bentuk stupika yang berkembang ini merupakan wujud kreativitas masyarakat Buddha di Nusantara.

\section{DAFTAR PUSTAKA}

Basuki, Hariawan Winantu,1992. Stupika Borobudur Teknologi Pembuatan dan Fungsi. Skripsi S1, Yogyakarta: Fakultas Sastra UGM

Boechari, Wiwin Djuwita dan Heriyanti Ongkodharma,1982. Report on Clay Votive Stupas from the Borobudur site dalam Pelita Borobudur seri CC no.8. Jakarta: Departemen Pendidikan dan Kebudayaan

Chutiwongs, Nandana, 1984 The Iconography of Avalokitesvara in mainland Southeast Asia, Ph.D thesis Rijksuniversiteit, Leiden : Rijkuniversiteit, 1994 An Aspect of the Boddhisattva Avalokitesvara in Ancient Indonesia in Ancient Indonesia Sculpture, Leiden: KITLV Press p. 98 - 114

Guy,John, 2002 Offering up a Rare Jewl : Buddhist meritmaking and votive Tablets in Early Burma on Burma Art and Archaeology, London: The British Museum Press p. 23-33

Hardiati, Endang Sri, 1983. Stupikas dan Votive Tablets Found in Indonesia " Consultative Workshop on Archaeological And Environment Studies on Srivijaya, Bangkok: SPAFA

Sumadio,Bambang (ed). 1990. Zaman Kuna dalam Marwati Djoened Poesponegoro dkk, Sejarah Nasional Indonesia 2 Jakarta: Balai Pustaka

I made Sutaba dkk, 1992. Pura Pegulingan Temuan Baru Tentang Persebaran Agama Buddha di Bali, Denpasar: SPSP Bali-NTB-NTT-Timtim, Bali

Issatriadi, 1976 Stupika Tanah Liat Bermaterai Gumuk Klinting, Jawa Timur : Proyek Rehabilitasi dan Perluasan Museum

O'Connor, Stanley J., 1974 "Buddhist Votive Tablets and Caves in Peninsular Thailand", in Art and Archaeology in Thailand: In Commemoration of the 100th anniversary of the National Museum.- Bangkok: Fine Arts Department, 1974: 67-84.,

Tatakususu. J., 1896. A Record of the Buddhist Religion as Practiced in India and The Malay Archipelago by I-Tsing. New York : Oxford at the Clarendon Press. 